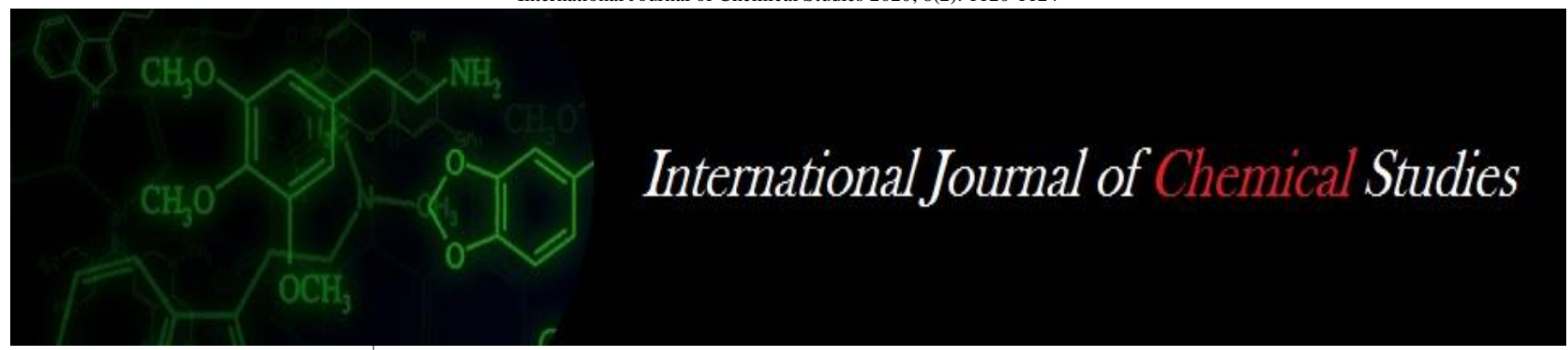

P-ISSN: 2349-8528

E-ISSN: 2321-4902

www.chemijournal.com

IJCS 2020; 8(2): 1120-1124

(C) 2020 IJCS

Received: 14-01-2020

Accepted: 18-02-2020

Ashvini Gaidhani

Ph.D., Scholar, Department of

Floriculture and Landscape

Architecture, Dr. P.D.K.V.,

Akola, Maharashtra, India

\section{SR Dalal}

Head, Horticulture Section,

College of Agriculture, Dr.

P.D.K.V., Akola, Maharashtra,

India

\section{PK Nagre}

Head, Faculty of Horticulture and Dean, College of

Horticulture, Dr. P.D.K.V., Akola, Maharashtra, India

Corresponding Author: Ashvini Gaidhani

Ph.D., Scholar, Department of Floriculture and Landscape Architecture, Dr. P.D.K.V., Akola, Maharashtra, India

\section{Effect of different planting dates and pinching on growth and flowering of China aster}

\section{Ashvini Gaidhani, SR Dalal and PK Nagre}

DOI: https://doi.org/10.22271/chemi.2020.v8.i2q.8918

\begin{abstract}
A field investigation was carried out at Floriculture Unit, Department of Horticulture, Dr. PDKV, Akola during the years, 2017-18 and 2018-19 in Factorial Randomized Block Design. Experiment comprising two factors i.e. factor "A" which consists of different planting dates (D) viz. $1^{\text {st }}$ September, $15^{\text {th }}$ September, $1^{\text {st }}$ October and $15^{\text {th }}$ October and factor "B" consists of different pinching $(\mathrm{P})$ viz. no pinching, single pinching at 20 DAT and single pinching at 30 DAT with 12 treatment combinations and replicated thricely. The results of the experiment revealed that, in respect of growth parameters viz. number of primary branches, number of secondary branches, plant spread, leaf area and stem diameter were observed maximum in $15^{\text {th }}$ September planting date and single pinching at 20 DAT treatment. However, plant height was obtained in $15^{\text {th }}$ September planting date and no pinching treatment. In respect of flowering parameters, minimum days for emergence of first flower bud, days required to full opening of flower from bud initiation, days for 50 per cent flowering and days to first harvesting were recorded in $15^{\text {th }}$ September planting date and no pinching treatment. However, maximum duration of flowering was obtained in $15^{\text {th }}$ September planting date and single pinching at 20 DAT during both the years of the experimentation.
\end{abstract}

Keywords: China aster, pinching, planting date, growth, flowering

\section{Introduction}

Among the wide range of commercial flower crops, China aster occupies a selective position because of its prettiness, elegance diverse form and varied attractive colour ranges. It is native to China and has spread to Europe and other Tropical countries during 1731 A.D (Desai, 1967) [4]. China aster is mainly cultivated for production of cut flowers, loose flowers, as pot plant and for bedding plant purposes in landscape. Dwarf types are highly suitable for edging and window boxes. Long stalk flowers are used in vases for decoration, preparation of bouquets and loose flowers are used in garland making.

The farmers in this region generally raise this crop in rabi season. However, due to lack of standard production technology, the yield of quality flowers and seed per unit area is low and therefore, the planting of aster at suitable time is considered most important. The importance of cultural practices for increasing the yield of quality flowers and seed is well known. It is, therefore, essential to find the most suitable planting time for raising of aster. This can be achieved with planting of suitable cultivars and pinching of terminal growth at suitable intervals. Pinching alleviates the effect of apical dominance (Cline, 1997) ${ }^{[2]}$ and this practice alters the source and sink relationship leading to higher yield.

Hence, it is necessary to identify the suitable cultivar for commercial cultivation in Vidarbha region and even it is felt necessary to find out suitable planting date and pinching time for China aster to get better yields. Considering the economic importance of the crop, the present work is designed to effect of different planting dates and their suitability for growth, flowering characteristics of China aster.

\section{Materials and Methods}

This experiment was conducted in Factorial Randomized Block Design with three replications at Floriculture Unit, Department of Horticulture, Dr. PDKV, Akola during the years 2017-18 and 2018-19. The allotment of treatments to the various plots were done randomly in each replication. 
Experiment comprising two factors i.e. factor "A" consists of different planting dates (D) viz. $1^{\text {st }}$ September, $15^{\text {th }}$ September, $1^{\text {st }}$ October and $15^{\text {th }}$ October and factor " $\mathrm{B}$ " consists of different pinching (P) viz. no pinching, single pinching at 20 DAT and single pinching at 30 DAT with 12 treatment combinations.

Seeds were sown one month before planting in well prepared nursery beds. Well grown seedlings at two leaf pair stage were transplanted at 4 different planting dates starting from $1^{\text {st }}$ September to $15^{\text {th }}$ October at an interval of fifteen days. Seedlings were transplanted in well prepared flat beds at a spacing of $45 \times 30 \mathrm{~cm}$ in plot size $2.25 \mathrm{~m} \mathrm{x} 1.80 \mathrm{~m}$ while transplanting, the soil was pressed firmly around the seedlings and watered thoroughly. Pinching operation was done as per treatments. The crop was applied @ 10 tonnes of FYM, 150:50:50 NPK ha ${ }^{-1}$. Half does of nitrogen, full does of $\mathrm{P}$ and $\mathrm{K}$ were given at the time of transplanting and remaining half dose of nitrogen was applied 30 DAT. Intercultural operation, irrigation and plant protection measures were done as and when required. Recorded pooled data for two consecutive years were analyzed as per method suggested by Panse and Sukhatme (1995) for Factorial Randomized Block Design.

\section{Results and Discussion}

The results obtained from present investigation are presented below on the basis of pooled mean of two years of experimentation (2017-2018 and 2018-2019).

\section{Growth parameters}

\section{Effect of planning dates}

The experimental finding indicated that different planting dates were significantly influenced the growth parameters (Table 1). Significantly maximum plant height at 90 DAT $(43.87 \mathrm{~cm})$, number of primary branches at 60 DAT (4.25) and stem diameter at 90 DAT $(1.51 \mathrm{~cm})$ were noticed in $15^{\text {th }}$ September planting date and was at par with the $1^{\text {st }}$ September planting date similarly number of secondary branches (19.61), plant spread $(28.05 \mathrm{~cm})$ and leaf area $\left(24.46 \mathrm{~cm}^{2}\right)$ were recorded maximum in $15^{\text {th }}$ September planting date which were significantly superior than rest of all the treatments. This was followed by the $1^{\text {st }}$ September planting date. However, significantly minimum plant height at 90 DAT $(38.82 \mathrm{~cm})$, number of primary branches at 60 DAT (3.34), number of secondary branches (13.50), plant spread $(20.95 \mathrm{~cm})$, leaf area $\left(16.41 \mathrm{~cm}^{2}\right)$ and stem diameter at 90 DAT $(1.39 \mathrm{~cm})$ were recorded in $15^{\text {th }}$ October planting date.

The maximum plant height under $15^{\text {th }}$ September planting might be due to favorable growing conditions available during the period. During this period the maximum and minimum temperature were $32.2^{\circ} \mathrm{C}$ and $23.3^{\circ} \mathrm{C}$, respectively. Likewise, the relative humidity was also found to be maximum (90\%) during this period. This congenial temperature and humidity might have helped the plants to acquire more plant height and more number of branches. These results are in close agreement with the findings of Priyanka et al. (2013) ${ }^{[8]}$ who observed maximum plant height with planting in $17^{\text {th }}$ September in Helichrysum. The leaf area of China aster was less in late transplanting despite having prolonged growing period. It might be due to the presence of more number of leaves. The food reserves diverted to maintain the higher number of leaves and not increase the leaf area. These finding are supported by Kulkarni et al. (2008) ${ }^{[8]}$ in Chrysanthmum.

\section{Effect of pinching}

The growth parameters included plant height at 90 DAT, number of primary branches at 60 DAT, number of secondary branches, plant spread, leaf area at 50 per cent flowering, stem diameter at 90 DAT and presented in Table 1.

The data revealed significant differences among the treatments in respect of growth parameters. Plant height at 90 DAT was recorded significantly maximum $(47.85 \mathrm{~cm})$ in no pinching treatment. This was followed by treatment single pinching at 20 DAT. In pinching, removal of the apical growth or top shoots from plant, arrested the vertical growth of plant therefore, pinching reduced the plant height and it is obvious that more plant height was recorded by control treatment (no pinching) and reduction in plant height was found due to pinching treatments. These results are in close agreement with the findings of Sehrawat et al. (2003) ${ }^{[12]}$ in $T$. erecta., Dalal et al. (2006) ${ }^{[3]}$ in Carnation and Sailaja et al. (2013) ${ }^{[11]}$ in China aster.

Number of primary branches at 60 DAT (4.69), number of secondary branches $(23.74)$, plant spread $(27.62 \mathrm{~cm})$, leaf area $\left(23.86 \mathrm{~cm}^{2}\right)$ and stem diameter at 90 DAT $(1.50 \mathrm{~cm})$ were recorded maximum in single pinching at 20 DAT which was significantly superior than rest of all the treatments. This was followed by treatment single pinching at 30 DAT. However, significantly minimum number of primary branches at 60 DAT (3.35), number of secondary branches (5.56), plant spread $(20.67 \mathrm{~cm})$, leaf area $\left(16.68 \mathrm{~cm}^{2}\right)$ and stem diameter at 90 DAT $(1.40 \mathrm{~cm})$ were recorded in no pinching treatment. In pinching, the apical portion of main stem was removed and therefore, more side branches were formed below pinched portion. This is due to diversion of carbohydrates or food material towards the axiliary vegetative bud below pinched portion and neutralized the effect of apical dominance, which caused a cessation of further plant leading to shortest height and more number of primary branches. Therefore, there were increases in the plant spread, leaf area and stem diameter. These results are in close agreement with and findings of Sharma et al. (2012) ${ }^{[13]}$ and Maharnor et al. (2011) ${ }^{[7]}$ in African marigold and Sailaja et al. (2013) ${ }^{[11]}$ in China aster.

\section{Interaction effect}

Data presented in Table 3. Interaction effect due to planting dates and pinching was found to be non-significant in respect of different growth parameter except number of secondary branches the treatment combination $\mathrm{D}_{2} \mathrm{P}_{2}$ recorded maximum number of secondary branches (27.37) which was significantly superior than rest of all the treatment combinations. This was followed by the treatment combinations $\mathrm{D}_{1} \mathrm{P}_{2}$ (25.28) and $\mathrm{D}_{2} \mathrm{P}_{3}$ (25.20) and were at par with each other. However, significantly minimum number of secondary branches (4.75) were recorded by the treatment combination $\mathrm{D}_{4} \mathrm{P}_{1}$. Similarly, the treatment combination $\mathrm{D}_{2} \mathrm{P}_{2}$ recorded maximum plant spread $(31.44 \mathrm{~cm})$ which was significantly superior than rest of all the treatment combinations. This was followed by the treatment combinations $\mathrm{D}_{1} \mathrm{P}_{2}(28.52 \mathrm{~cm})$ and $\mathrm{D}_{2} \mathrm{P}_{3}(27.29 \mathrm{~cm})$ and were at par with each other. However, significantly minimum plant spread $(16.40 \mathrm{~cm})$ was recorded by the treatment combination $\mathrm{D}_{4} \mathrm{P}_{1}$.

\section{Flowering parameters Effect of planning dates}

The observations recorded on flowering parameters are given in Table 2. Significant differences were recorded among the different treatments. Significantly minimum days for emergence of first flower bud (48.12 days), days required to full opening of flower from bud initiation (15.02 days), days 
for 50 per cent flowering (59.76 days), days to first harvesting (62.82 days) and duration of flowering (28.87 days) were recorded in $15^{\text {th }}$ September planting date compared to other treatments. This was followed by $1^{\text {st }}$ September planting date. However, significantly maximum days for emergence of first flower bud (56.47 days), days required to full opening of flower from bud initiation (20.10 days), days for 50 per cent flowering (72.03 days), days to first harvesting (75.61 days) and duration of flowering (20.56 days) were recorded in $15^{\text {th }}$ October planting date.

Early flowering could be due to exposure of plants to short day and low temperature conditions during growth period, which favours flowering in aster, as result they entered early into the reproductive phase. Similar finding were reported by Barman et al. (1993) ${ }^{[1]}$. Aster being a short day plant, short photoperiod and moderate temperature prevailing during $15^{\text {th }}$ September planting date promoted earlier full opening of flower from bud initiation. Lakshmi et al. (2014) ${ }^{[6]}$ reported that, in October planting there were short day conditions which resulted in the formation of flower buds in lesser time period in African marigold. This might be due to early flowering thus exposure of plants to short day and low temperature conditions during growth period, which favours flowering in aster, as result they entered early into the reproductive phase. Similar results were also reported by Sruthi et al. (2016) ${ }^{[15]}$ in African marigold.

\section{Effect of pinching}

The data presented in Table 2 showed significant differences among the different treatments in respect of flowering parameters. Significantly minimum days for emergence of first flower bud (48.33 days), days required to full opening of flower from bud initiation (13.28 days), days for 50 per cent flowering (60.56 days), days to first harvesting (65.48 days) were recorded significantly in no pinching treatment compared to other treatments. This was followed by treatment single pinching at 20 DAT. However, significantly maximum days for emergence of first flower bud (55.30 days), days required to full opening of flower from bud initiation (21.03 days), days for 50 per cent flowering (70.22 days) and days to first harvesting (72.09 days) were recorded in single pinching at 30 DAT.

In general, pinching delayed flower bud initiation. The minimum days for emergence of first flower bud was recorded in control treatment where no pinching was performed. This delay might be due to repetitive removal of apical portion, due to which phenomenon of "Apical dominance" get breaked in pinch shoots and thus took longer time to become physiological mature for flowering. From above result it is noticed that, pinching delayed flowering. The delay in flowering by pinching due to removal of mature portion and new shoots which emerged out from pinched plants took more time to become physiological inductive to produced flower than non-pinched plant. These results are in close agreement with the finding of Sehrawat et al. (2003) ${ }^{[12]}$ in Marigold. The above findings thus agreed with results obtained by Dalal (2006) ${ }^{[3]}$ and Sailaja (2013) ${ }^{[11]}$ reported that, pinching significantly delayed first flowering compared with the control, with the most delay in the double pinch treatment in aster.

Duration of flowering (26.54 days) was recorded significantly maximum in single pinching at 20 DAT compared to other treatments. This was followed by treatment single pinching at 30 DAT. Pinching require one and half months period from induction to flower initiation might be due to the shoot tip pinching, that increased the number of primary branches and leaves plant ${ }^{-1}$ which helps to maximize duration of flowering than control, whereas annual chrysanthemum grown without pinching was ready within a month (Shrutika et al., 2017) ${ }^{[14]}$.

\section{Interaction effect}

Data presented in Table 3. Interaction effect due to planting dates and pinching was found to be non-significant in respect of different flowering parameters in respect of except days for 50 per cent flowering the treatment combination $\mathrm{D}_{2} \mathrm{P}_{1}$ recorded minimum days to $50 \%$ flowering (58.74 days) which was significantly superior than rest of all the treatment combinations. This was followed by the treatments combinations $\mathrm{D}_{2} \mathrm{P}_{2}$ (59.94 days) and $\mathrm{D}_{1} \mathrm{P}_{1}$ (59.67 days) and were found at par with each other. However, significantly maximum days to $50 \%$ flowering (79.77 days) were recorded by the treatment combination $\mathrm{D}_{4} \mathrm{P}_{3}$. The interaction effect of planting dates and pinching recorded significant effect on days to $50 \%$ flowering this indicates that along with pinching and planting dates also influences flowering in aster. Similar trend was found by Sruthi et al. (2016) ${ }^{[15]}$ and reported that, heavy rain and low sunshine hours in monsoon season have a role in delaying physiological maturity in different treatments of African marigold.

However, maximum duration of flowering was obtained in the treatment combination $\mathrm{D}_{2} \mathrm{P}_{2}$ recorded maximum duration of flowering (32.00 days) which was significantly superior than rest of all the treatment combinations. This was followed by the treatments combinations $\mathrm{D}_{1} \mathrm{P}_{2}$ (28.83 days), $\mathrm{D}_{2} \mathrm{P}_{1}$ (27.91 days) and $\mathrm{D}_{2} \mathrm{P}_{3}$ (26.71 days) and were found at par with each other. However, significantly minimum duration of flowering (20.75 days) was recorded by the treatment combination $\mathrm{D}_{3} \mathrm{P}_{1}$.

Table 1: Effect of different planting dates and pinching on growth parameters of China aster

\begin{tabular}{|c|c|c|c|c|c|c|c|c|c|c|c|c|c|c|c|c|c|c|}
\hline \multirow{2}{*}{ Treatments } & \multicolumn{3}{|c|}{$\begin{array}{l}\text { Plant height at } 90 \\
\text { DAT }(\mathrm{cm})\end{array}$} & \multicolumn{3}{|c|}{$\begin{array}{l}\text { Number of primary } \\
\text { branches at } 60 \mathrm{DAT}\end{array}$} & \multicolumn{3}{|c|}{$\begin{array}{c}\text { Number of secondary } \\
\text { branches }\end{array}$} & \multicolumn{3}{|c|}{$\begin{array}{l}\text { Plant spread } \\
\quad(\mathrm{cm})\end{array}$} & \multicolumn{3}{|c|}{ Leaf area $\left(\mathbf{c m}^{2}\right)$} & \multicolumn{3}{|c|}{$\begin{array}{c}\text { Stem diameter at } 90 \\
\text { DAT }(\mathrm{cm})\end{array}$} \\
\hline & 2017-18 & $\begin{array}{c}2018- \\
19\end{array}$ & Pooled & & $\begin{array}{c}2018 \\
-19 \\
\end{array}$ & Pooled & 2017-18 & 2018-19 & Pooled & $\begin{array}{c}2017- \\
18\end{array}$ & \begin{tabular}{c|}
$2018-$ \\
19
\end{tabular} & $\begin{array}{c}\text { Pool } \\
\text { ed }\end{array}$ & $\begin{array}{c}2017 \\
18\end{array}$ & $\begin{array}{c}2018- \\
19\end{array}$ & $\begin{array}{c}\text { Pool } \\
\text { ed }\end{array} \mid 2$ & & & Polo \\
\hline \multicolumn{19}{|c|}{ Factor A. Planting dates (D) } \\
\hline & & & & & & & & & & 24.73 & & 25.59 & 20.73 & & 21.48 & & & \\
\hline $\mathrm{D}_{2}-1$ & & & & & 42 & & & & & 26.30 & & & & & 24.46 & & & \\
\hline$D_{3}-1$ & & & & & 3.8 & & & & & 22.59 & 24. & 23.60 & 18.82 & 19.53 & 19.18 & & & \\
\hline $\mathrm{D}_{4}-15$ & 38.16 & 39.49 & 38.8 & & 3.41 & & & 13. & 13.50 & 19.63 & 22.26 & 20.95 & 15.96 & 16.87 & 16.41 & 1.39 & 1.40 & 1.39 \\
\hline F & & Sig. & & & & & & & & \begin{tabular}{|l|} 
Sig. \\
\end{tabular} & \begin{tabular}{|l|} 
Sig. \\
\end{tabular} & \begin{tabular}{|l|} 
Sig. \\
\end{tabular} & \begin{tabular}{|l|} 
Sig. \\
\end{tabular} & Sig. & Sig. & & & Sig. \\
\hline $\mathrm{SE}(\mathrm{m}) \pm$ & & 0.7 & & & 0.13 & & & & & 0.47 & 0.66 & 0.36 & 0.63 & 0.65 & 0.60 & 0.0 & 32 & 0.029 \\
\hline & 2.47 & 2.15 & & & \begin{tabular}{|c|}
0.39 \\
\end{tabular} & 0.38 & 1.46 & 1.98 & 1.68 & 1.37 & 1.93 & 1.05 & 1.83 & 1.91 & 1.75 & 0.079 & 0.094 & 0.085 \\
\hline \multicolumn{19}{|c|}{ tor B. Pinching (P) } \\
\hline & & & & & & & & & & & & 20.67 & & & 16.68 & & & \\
\hline $\mathrm{P}_{2}-$ Single pinching & 38.51 & 40.55 & 39.53 & 4.65 & 4.73 & 4.69 & 23.31 & 24.17 & 23.74 & 27.14 & 28.10 & 27.62 & 22.99 & 24.73 & 23.86 & 1.49 & 1.51 & 1.50 \\
\hline
\end{tabular}




\begin{tabular}{|c|c|c|c|c|c|c|c|c|c|c|c|c|c|c|c|c|c|c|}
\hline at $20 \mathrm{DAT}$ & & & & & & & & & & & & & & & & & & \\
\hline $\begin{array}{c}\mathrm{P}_{3}-\text { Single pinching } \\
\text { at } 30 \mathrm{DAT}\end{array}$ & 36.02 & 36.78 & 36.40 & 3.47 & 3.57 & 3.52 & 19.83 & 20.56 & 20.20 & 24.46 & 26.26 & 25.36 & 20.10 & 21.13 & 20.61 & 1.47 & 1.49 & 1.48 \\
\hline 'F' Test & Sig. & Sig. & Sig. & Sig. & Sig. & Sig. & Sig. & Sig. & Sig. & Sig. & Sig. & Sig. & Sig. & Sig. & Sig. & Sig. & Sig. & Sig. \\
\hline $\mathrm{SE}(\mathrm{m}) \pm$ & 0.73 & 0.64 & 0.62 & 0.12 & 0.11 & 0.11 & 0.43 & 0.59 & 0.50 & 0.40 & 0.57 & 0.36 & 0.54 & 0.57 & 0.52 & 0.023 & 0.028 & 0.025 \\
\hline $\mathrm{CD}$ at $5 \%$ & 2.14 & 1.87 & 1.83 & 0.34 & 0.34 & 0.33 & 1.26 & 1.72 & 1.46 & 1.19 & 1.67 & 1.05 & 1.59 & 1.66 & 1.51 & 0.068 & 0.081 & 0.074 \\
\hline
\end{tabular}

Table 2: Effect of different planting dates and pinching on flowering parameters of China aster

\begin{tabular}{|c|c|c|c|c|c|c|c|c|c|c|c|c|c|c|c|}
\hline \multirow[t]{2}{*}{ Treatments } & \multicolumn{3}{|c|}{$\begin{array}{c}\text { Days for emergence } \\
\text { of first flower bud (days) }\end{array}$} & \multicolumn{3}{|c|}{$\begin{array}{c}\text { Days required to } \\
\text { full opening of flower } \\
\text { from bud initiation (days) }\end{array}$} & \multicolumn{3}{|c|}{$\begin{array}{l}\text { Days to } 50 \text { per } \\
\text { cent flowering (days) }\end{array}$} & \multicolumn{3}{|c|}{$\begin{array}{c}\text { Days to first } \\
\text { harvesting (days) }\end{array}$} & \multicolumn{3}{|c|}{$\begin{array}{l}\text { Duration of flowering } \\
\text { (days) }\end{array}$} \\
\hline & 2017-18 & 2018-19 & Pooled & 2017-18 & 2018-19 & Pooled & 2017-18 & 2018-19 & Pooled & 2017-18 & 2018-19 & Pooled & 2017-18 & 2018-19 & Pooled \\
\hline \multicolumn{16}{|c|}{\begin{tabular}{|l|l|l|l|l|l|l|l|l|l|l|l|} 
Factor A. Planting dates (D) & & & & & & & & & & & \\
\end{tabular}} \\
\hline$D_{1}-1^{\text {st }}$ September & 51.93 & 50.44 & 51.19 & 17.18 & 16.26 & 16.72 & 63.97 & 61.05 & 62.51 & 67.51 & 65.72 & 66.62 & 24.92 & 25.62 & 25.27 \\
\hline $\mathrm{D}_{2}-15^{\text {th }}$ September & 49.05 & 47.18 & 48.12 & 15.62 & 14.41 & 15.02 & 60.81 & 58.71 & 59.76 & 64.24 & 61.39 & 62.82 & 28.02 & 29.73 & 28.87 \\
\hline $\mathrm{D}_{3}-1^{\text {st }}$ October & 54.77 & 53.24 & 54.01 & 19.09 & 18.07 & 18.58 & 68.98 & 66.25 & 67.62 & 73.03 & 71.13 & 72.08 & 22.60 & 24.27 & 23.44 \\
\hline $\mathrm{D}_{4}-15^{\text {th }}$ October & 57.55 & 55.38 & 56.47 & 20.33 & 19.87 & 20.10 & 73.04 & 71.02 & 72.03 & 76.38 & 74.83 & 75.61 & 19.41 & 21.70 & 20.56 \\
\hline 'F' test & Sig. & Sig. & Sig. & Sig. & Sig. & Sig. & Sig. & Sig. & Sig. & Sig. & Sig. & Sig. & Sig. & Sig. & Sig. \\
\hline $\mathrm{SE}(\mathrm{m}) \pm$ & 1.11 & 0.99 & 1.01 & 0.71 & 0.74 & 0.67 & 1.38 & 1.80 & 1.20 & 1.52 & 1.31 & 1.33 & 0.85 & 0.79 & 0.69 \\
\hline $\mathrm{CD}$ at $5 \%$ & 3.26 & 2.90 & 2.96 & 2.08 & 2.16 & 1.95 & 4.04 & 5.28 & 3.52 & 4.47 & 3.85 & 3.91 & 2.48 & 2.32 & 2.04 \\
\hline \multicolumn{16}{|c|}{ Factor B. Pinching (P) } \\
\hline $\mathrm{P}_{1}$ - No pinching & 49.19 & 47.48 & 48.33 & 13.95 & 12.6 & 13.28 & 61.73 & 59.39 & 60.56 & 65.93 & 65.03 & 65.48 & 21.93 & 23.63 & 22.74 \\
\hline $\begin{array}{c}\mathrm{P}_{2}-\text { Single pinching } \\
\text { at } 20 \text { DAT }\end{array}$ & 54.49 & 52.91 & 53.70 & 18.59 & 18.42 & 18.50 & 66.75 & 64.58 & 65.66 & 71.18 & 69.37 & 70.27 & 25.44 & 27.63 & 26.54 \\
\hline $\begin{array}{c}\mathrm{P}_{3}-\text { Single pinching } \\
\text { at } 30 \text { DAT }\end{array}$ & 56.31 & 54.30 & 55.30 & 21.63 & 20.43 & 21.03 & 71.63 & 68.81 & 70.22 & 73.78 & 70.41 & 72.09 & 23.84 & 24.8 & 24.32 \\
\hline 'F' Test & Sig. & Sig. & Sig. & Sig. & Sig. & Sig. & Sig. & Sig. & Sig. & Sig. & Sig. & Sig. & Sig. & Sig. & Sig. \\
\hline & 0.96 & 0.86 & 0.87 & 0.61 & 0.64 & 0.58 & 1.19 & 1.56 & 1.04 & 1.32 & 1.14 & 1.16 & 0.73 & 0.68 & 0.60 \\
\hline $\mathrm{CD}$ at $5 \%$ & 2.82 & 2.51 & 2.57 & 1.80 & 1.87 & 1.69 & 3.50 & 4.57 & 3.05 & 3.87 & 3.34 & 3.39 & 2.15 & 2.01 & 1.76 \\
\hline
\end{tabular}

Table 3: Interaction effect of different planting dates and pinching on growth and flowering parameters of China aster

\begin{tabular}{|c|c|c|c|c|c|c|c|c|c|c|c|c|}
\hline \multirow{2}{*}{$\begin{array}{c}\text { Treatment } \\
\text { combinations }\end{array}$} & \multicolumn{3}{|c|}{$\begin{array}{c}\text { Number of secondary } \\
\text { branches }\end{array}$} & \multicolumn{3}{|c|}{ Plant spread (cm) } & \multicolumn{3}{|c|}{$\begin{array}{l}\text { Days to } 50 \text { per cent flowering } \\
\text { (days) }\end{array}$} & \multicolumn{3}{|c|}{$\begin{array}{c}\text { Duration of flowering } \\
\text { (days) }\end{array}$} \\
\hline & 2017-18 & 2018-19 & Pooled & 2017-18 & 2018-19 & Pooled & 2017-18 & 2018-19 & Pooled & $2017-18$ & \begin{tabular}{|l|}
$2018-19$ \\
\end{tabular} & Pooled \\
\hline \multicolumn{13}{|c|}{ Planting dates $\mathbf{x}$ Pinching } \\
\hline $\mathrm{D}_{1} \mathrm{P}_{1}$ & 5.97 & 6.13 & 6.05 & 18.5 & 24.65 & 21.58 & 60.07 & 59.27 & 59.67 & 20.91 & 21.90 & 21.40 \\
\hline $\mathrm{D}_{1} \mathrm{P}_{2}$ & 24.90 & 25.67 & 25.28 & 29.05 & 27.98 & 28.52 & 65.60 & 62.80 & 64.20 & 27.96 & 29.70 & 28.83 \\
\hline $\mathrm{D}_{1} \mathrm{P}_{3}$ & 19.53 & 20.47 & 20.00 & 26.63 & 26.75 & 26.69 & 66.23 & 61.09 & 63.66 & 25.89 & 25.26 & 25.58 \\
\hline $\mathrm{D}_{2} \mathrm{P}_{1}$ & 6.13 & 6.40 & 6.27 & 21.39 & 29.47 & 25.43 & 59.52 & 57.97 & 58.74 & 26.38 & 29.44 & 27.91 \\
\hline $\mathrm{D}_{2} \mathrm{P}_{2}$ & 26.53 & 28.20 & 27.37 & 30.80 & 32.07 & 31.44 & 61.14 & 58.74 & 59.94 & 31.55 & 32.44 & 32.00 \\
\hline $\mathrm{D}_{2} \mathrm{P}_{3}$ & 24.67 & 25.73 & 25.20 & 26.71 & 27.87 & 27.29 & 61.78 & 59.42 & 60.60 & 26.12 & 27.30 & 26.71 \\
\hline $\mathrm{D}_{3} \mathrm{P}_{1}$ & 5.10 & 5.23 & 5.17 & 17.24 & 21.26 & 19.25 & 63.13 & 59.73 & 61.43 & 19.95 & 21.55 & 20.75 \\
\hline $\mathrm{D}_{3} \mathrm{P}_{2}$ & 22.70 & 23.47 & 23.08 & 25.30 & 26.25 & 25.78 & 66.09 & 63.10 & 64.59 & 23.95 & 27.51 & 25.73 \\
\hline $\mathrm{D}_{3} \mathrm{P}_{3}$ & 18.67 & 19.43 & 19.05 & 25.23 & 26.28 & 25.76 & 77.73 & 75.93 & 76.83 & 23.89 & 23.76 & 23.83 \\
\hline $\mathrm{D}_{4} \mathrm{P}_{1}$ & 4.63 & 4.87 & 4.75 & 16.24 & 16.57 & 16.40 & 64.20 & 60.61 & 62.40 & 20.48 & 21.33 & 20.91 \\
\hline $\mathrm{D}_{4} \mathrm{P}_{2}$ & 19.10 & 19.33 & 19.22 & 23.40 & 26.09 & 24.75 & 74.16 & 73.66 & 73.91 & 18.29 & 20.89 & 19.59 \\
\hline $\mathrm{D}_{4} \mathrm{P}_{3}$ & 16.47 & 16.6 & 16.53 & 19.27 & 24.13 & 21.70 & 80.75 & 78.79 & 79.77 & 19.47 & 22.87 & 21.17 \\
\hline 'F' Test & Sig. & Sig. & Sig. & Sig. & Sig. & Sig. & Sig. & Sig. & Sig. & Sig. & Sig. & Sig. \\
\hline $\mathrm{SE}(\mathrm{m}) \pm$ & 0.86 & 1.17 & 0.99 & 0.81 & 1.14 & 0.72 & 2.38 & 3.12 & 2.08 & 1.47 & 1.37 & 1.20 \\
\hline $\mathrm{CD}$ at $5 \%$ & 2.53 & 3.44 & 2.91 & 2.38 & 3.34 & 2.10 & 6.99 & 9.14 & 6.10 & 4.30 & 4.01 & 3.53 \\
\hline
\end{tabular}

\section{Acknowledgement}

Authors would like to acknowledge to all the staff and friends from Department of Horticulture, Dr. PDKV, Akola for their help during this investigation.

\section{References}

1. Barman D, Ghosh S, Pal P. Effect of planting date and pinching height on flowering of chrysanthemum. Horti. J. 1993; 6:121-124.

2. Cline MG. Concepts and terminology of apical dominance. American J Botany. 1997; 84(9):1064-1069.

3. Dalal SR, Nandre DR, Bharad SG, Swarupa Utgikar, Shinde RD. Effect of pinching on carnation cv. Yellow Solar under polyhouse condition. Inter. J Agric. Sci. 2006; 2(2):356-357.

4. Desai B. Seasonal flowers. ICAR.: New Delhi, 1967, 237.
5. Kulkarni BS, Reddy BS. Effect of different dates of planting on growth and flowering of Chrysanthemum (Chrysanthemum moriflium Ramat). J Orna. Hort. 2008; 11(3):177-180.

6. Lakshmi R, Pandey K, Sheetal Dogra, Nomita Laishram, Deepji Bhat, Singh A et al. Studies on effects of planting dates and spacing in African marigold (Tagets erecta L.). Prog. Hort. 2014; 46(1):149-152.

7. Maharnor SI, Neha Chopde, Seema Thakre, Raut PD. Effect of nitrogen and pinching on growth and yield of African marigold. Asian J Hort. 2011; 6(1):43-45.

8. Priyanka Sharma, Gupta YC, Dhiman SR, Puja Sharma, Bhavya Bhargava. Effect of planting dates on growth, flowering and seed production of paper flower (Helichrysum bracteatum Andr.) under mid hills of Himachal Pradesh. Ind. J App. Res. 2013; 3(11):1-3. 
9. Panse VG, Sukhatme. Statistical Methods for Agricultural Workers, New Delhi, Publication and information Division, ICAR, 1967.

10. Priyanka Sharma, Gupta YC, Dhiman SR, Puja Sharma, Bhavya Bhargava. Effect of planting dates on growth, flowering and seed production of paper flower (Helichrysum bracteatum Andr.) under mid hills of Himachal Pradesh. Ind. J App. Res. 2013; 3(11):1-3.

11. Sailaja SM, Panchbhai DM, Suneetha K. Response of China aster varieties to pinching for growth, yield and quality. Hort Flora Res. Spect. 2013; 2(4):366-368.

12. Sehrawat SK, Dahiya DS, Sukhbir Singh, Rana GS. Effect of nitrogen and pinching on the growth, flowering and yield of marigold (Tagetes erecta L.) cv. African Giant Double Orange. Haryana J Hort. Sci. 2003; 32(12):59-61.

13. Sharma AK, Chaudhary SVS, Bhatia RS. Effect of spacing and pinching on regulation of flowering in African marigold under submontane low hill condition of Himachal Pradesh. Prog. Agric. 2012; 12(2):331-336.

14. Shrutika Taksande, Raut VU, Nagre PK. Effect of pinching and cycocel on flowering and flower quality of annual Chrysanthemum. J Soils and Crops. 2017; 27(1):75-79.

15. Sruthi Prakash, Anitha P, Giridharan MP, Rajagopalan A, Sudarsana Rao GV. Impact of seasons and pinching on growth and flowering in African marigold (Tagetes erecta L.). J Tropical Agri. 2016; 54(1):50-54. 